\title{
Impact of temporomandibular disorder on oral health-related quality of life in
}

\section{adolescents}

\author{
Impacto da disfunção temporomandibular na qualidade de vida relacionada à saúde bucal em \\ adolescentes \\ Impacto de los trastornos temporomandibulares sobre calidad de vida relacionada a la salud bucal \\ en adolescentes
}

Gabrielle Amaral-Freitas

ORCID: https://orcid.org//0000-0001-6796-1496 Federal University of Minas Gerais, Brazil E-mail: gabrielle-amaral@hotmail.com

Ana Luiza Peres Baldiotti

ORCID: https://orcid.org//0000-0003-2814-3401 Federal University of Minas Gerais, Brazil E-mail: analuizapbaldiotti@hotmail.com

Rafaela Scariot

ORCID: https://orcid.org//0000-0002-4911-6413

Federal University of Paraná, Brazil E-mail: rafaela_scariot@yahoo.com.br

Mariane Carolina Faria Barbosa

ORCID: https://orcid.org//0000-0002-2870-8364 Federal University of Minas Gerais, Brazil

E-mail: marianecarolinabarbosa@ gmail.com

Maria Luísa Leandro de Souza Dias

ORCID: https://orcid.org//0000-0001-6850-764X Federal University of Minas Gerais, Brazil

E-mail: marialuisadesouzadias@gmail.com Maria Luíza Araújo Almeida

ORCID: https://orcid.org//0000-0002-7114-1957 Federal University of Minas Gerais, Brazil E-mail: contatomalluaraujo@gmail.com

Renata de Castro Martins

ORCID: https://orcid.org//0000-0002-8911-0040 Federal University of Minas Gerais, Brazil E-mail: rcmartins05@gmail.com

Saul Martins Paiva

ORCID: https://orcid.org//0000-0002-3968-1638 Federal University of Minas Gerais, Brazil E-mail: smpaiva@uol.com.br

Fernanda MoraisFerreira

ORCID: https://orcid.org//0000-0001-9400-1167 Federal University of Minas Gerais, Brazil E-mail: femoraisfe@gmail.com

\begin{abstract}
The aim of this cross-sectional study was to assess the impact of temporomandibular disorder (TMD) on oral healthrelated quality of life (OHRQoL) of adolescents. The OHRQoL of adolescents undergoing dental treatment at a University clinic in 2019 was measured using the Brazilian version of the Oral Heath Impact Profile - 14 (OHIP-14). The diagnosis of TMD was performed using Research Diagnostic Criteria for Temporomandibular disorders (RDC/TMD). The patients were examined for other oral conditions and the parents/guardians answered questions addressing socioeconomic/demographic characteristics and the general health of the adolescents. Statistical analysis involves simple and multiple logistic regression models. Ninety male and female adolescents between 13 and 18 years of age participated in the study. The prevalence of negative impact on OHRQoL was 34\%. In the unadjusted analysis, negative impact on OHRQoL was associated with a poorer self- perception of general and oral health of the adolescent, nonspecific symptoms including pain, and generalized anxiety disorder, caries, reports of dental pain, muscle disorders and disc displacement, and chronic pain related to TMD. In the adjusted model, negative impact on OHRQoL was associated with all diagnoses related to TMD on the RDC/TMD, except signs of depression.
\end{abstract}


Adolescents with at least one diagnosis related to TMD were 4.13-fold more likely (95\% CI:1.08-15.80) to have negative impact on OHRQoL than adolescents without a diagnosis of TMD. The different diagnostic categories of TMD had a negative impact on the OHRQoL of the adolescents analyzed in the present study.

Keywords: Quality of life; Oral health; Temporomandibular joint; Adolescent; Temporomandibular joint dysfunction syndrome.

\section{Resumo}

Esse estudo transversal objetivou avaliar o impacto da disfunção temporomandibular (DTM) na qualidade de vida relacionada à saúde bucal (QVRSB) de adolescentes. Pacientes entre 13-18 anos, em tratamento odontológico em uma clínica universitária no ano de 2019 tiveram sua QVRSB mensurada atraves da versão brasileira do Oral Heath Impact Profile - 14 (OHIP-14). O diagnóstico de DTM foi realizado atraves dos eixos I e II do RDC/TMD. Os pacientes foram examinados para outras condições bucais e seus pais/responsáveis responderam questões sociecônomicas, demográficas e de saúde geral dos adolescentes. A análise estátistica usou modelos simples e múltiplos de regressão logística. Noventa adolescentes, de ambos os sexos, participaram do estudo. A prevalência do impacto negativo na QVRSB foi de 34\%, sendo os domínios de maior impacto "Desconforto Psicológicos" (28\%) e "Incapacidade Psicológica" (19\%). O impacto negativo na QVRSB esteve associado, nas análises não ajustadas, a uma pior autopercepção de saúde geral e bucal do adolescente, depressão, sintomas inespecíficos incluindo dor e transtorno de ansiedade generalizada, cárie, relato de dor de dente, DTM, desordem muscular e articular e de dor crônica relacionada à DTM. No modelo ajustado, o impacto negativo na QVRSB foi associado a todos os diagnósticos relacionados à DTM no RDC/TMD, exceto sinais de depressão. Adolescentes com pelo menos um diagnóstico relacionado à DTM tinham chance 4,13 (IC95\%\%: 1,08-15,80) maior de apresentar impacto negativo na QVRSB do que adolescentes sem diagnóstico de DTM. DTM em suas diferentes categorias diagnósticas tiveram impacto negativo na QVRSB de adolescentes.

Palavras-chave: Qualidade de vida; Saúde bucal; Articulação temporomandibular; Adolescente; Síndrome da disfunção da articulação temporomandibular.

\section{Resumen}

El objetivo de este estudio transversal fue evaluar el impacto de los trastornos temporomandibulares (TTM) en la calidad de vida relacionada con la salud bucal (QARSO) de los adolescentes. La OHRQoL de adolescentes sometidos a tratamiento dental en una clínica universitaria en 2019 se midió utilizando la versión brasileña del Oral Health Impact Profile - 14 (OHIP-14). El diagnóstico de TMD se realizó utilizando los Criterios de diagnóstico de investigación para trastornos temporomandibulares (RDC / TMD). Los pacientes fueron examinados en busca de otras afecciones bucales y los padres / tutores respondieron preguntas sobre las características socioeconómicas / demográficas y la salud general de los adolescentes. El análisis estadístico implica modelos de regresión logística simple y múltiple. Participaron del estudio 90 adolescentes, hombres y mujeres, entre 13 y 18 años. La prevalencia de impacto negativo en la OHRQoL fue del 34\%. En el análisis no ajustado, el impacto negativo en la OHRQoL se asoció con una peor autopercepción de la salud general y bucal del adolescente, síntomas inespecíficos como dolor y trastorno de ansiedad generalizada, caries, informes de dolor dental, trastornos musculares y desplazamiento del disco, y dolor crónico relacionado con TMD. En el modelo ajustado, el impacto negativo en OHRQoL se asoció con todos los diagnósticos relacionados con TMD en el RDC / TMD, excepto los signos de depresión. Los adolescentes con al menos un diagnóstico relacionado con TMD tenían 4,13 veces más probabilidades (IC 95\%: 1,08-15,80) de tener un impacto negativo en la OHRQoL que los adolescentes sin un diagnóstico de TMD. Las diferentes categorías diagnósticas de TTM tuvieron un impacto negativo en la OHRQoL de los adolescentes analizados en el presente estudio.

Palabras clave: Calidad de vida; Salud bucal; Articulación temporomandibular; Adolescentes; Síndrome de la disfunción de articulación temporomandibular.

\section{Introduction}

Oral health is defined as physical, psychological, and social wellbeing related to the status of the oral cavity and is characterized by the absence of pain, discomfort, and abnormalities of the mouth and face(Locker, 2001; Glick et al., 2016). An imbalance in oral health can exerts a physical and psychological impact on functional aspects of speech, chewing, and taste as well as social aspects, such as wellbeing, subjective happiness, and self- esteem (Zucoloto et al.,2016; Blanco Aguilera et al., 2017; Bitiniene et al., 2018).

Oral health-related quality of life (OHRQoL) is a complex, multidimensional concept (Colussi et al., 2017). In recent decades, negative impact on OHRQoL has been measured in different age groups to understand the perceptions of individuals with regards to oral problems and their consequences as well as treatment needs and satisfaction with treatment (Cortes et al., 
2002; Jung, 2016; Blanco Aguilera et al., 2017; Bitiniene et al., 2018). The literature reports that dental caries, toothache, halitosis, dentoalveolar trauma, and malocclusion exert a negative impact on the OHRQoL of adolescents (Peres et al., 2009; Colussi et al., 2017; Keles et al., 2018; Thomson \& Broder, 2018). Moreover, low frequencies of tooth brushing and visits to the dentist, which are characteristics of adolescence, can also exert a negative impact on OHRQoL in this population (Keles et al., 2018).

Temporomandibular disorder (TMD) encompasses a broad range of conditions, the signs and symptoms of which involve the temporomandibular joints, masticatory muscles, and associated structures (Melis \& Di Giosia, 2016; Bitiniene $e t$ al., 2018). The prevalence of TMD varies among different populations and age groups and also depends on the diagnostic criteria employed (Bont et al., 1997; Sena et al., 2013). The prevalence of this disorder is widely investigated in the adult population, but studies demonstrate that TMD can begin in childhood and adolescence, which makes the study of this phase of life important to gaining a better understanding of its onset and evolution (Sonmez et al., 2001; Godoy et al., 2007, Karibe et al., 2015; Hongxing et al., 2016; Al-Khotani et al., 2016; Paiva Bertoli et al., 2018).

Muscle and joint symptoms, joint sounds, poor sleep quality, a sensation of tired, painful jaws upon waking, a lack of energy, and pain related to TMD have a negative impact on quality of life (Deli et al., 2009; Resende et al., 2013; Bitiniene et al., 2018) and OHRQoL (Miettinen et al., 2012; Lemos et al., 2015; Blanco Aguilera et al., 2017) in adults. However, such associations have been investigated few in adolescents (Barbosa et al., 2011). Therefore, the present study aimed to assess the impact of signs and symptoms of TMD on OHRQoL in Brazilian adolescents, when adjusted by general and oral health as well as psychological, socioeconomic, and demographic characteristics.

\section{Methodology}

\subsection{Ethical aspects}

The present study received approval from the institutional review board of Universidade Federal de Minas Gerais (certificate number: 01936918.8.0000.5149). Participation in the study was voluntary and authorized by the parents/guardians and individuals older than 18 years of age through a signed statement of informed consent. Adolescents under 18 years of age also signed a statement of consent.

\subsection{Study design and sample}

A cross-sectional study was conducted with a sample of adolescents. The inclusion criteria were 13 to 18 years of age, both sexes, undergoing care at the School of Dentistry of University. The exclusion criteria were currently undergoing orthodontic treatment, use of occlusal splints or dental prostheses, odontogenic pain, severe facial or dental anomalies, extensive tooth decay, and parental reports of cognitive/behavioral/speech problems or systemic disorders. The sample size was calculated considering a 95\% confidence level, $80 \%$ test power, and frequency of impact on OHRQoL of $41 \%$ and $18 \%$, among individuals with and without TMD respectively (Yap et al., 2020). The minimum sample size was determined to be 122 individuals (https://www.openepi.com/SampleSize/SSCC.htm).

\subsection{Variables of interest}

The parents/guardians answered a questionnaire addressing socioeconomic and demographic characteristics related to the adolescent (complete name, age, date of birth, and sex) and guardian (degree of kinship to adolescent, complete name, address, number of residents in the home, schooling, and monthly family income) as well as clinical information related to the adolescent (general health, use of medications,nail biting habit, otolaryngology problems, oral health, previous history of dental pain, history of facial muscle pain,and sleep quality/duration). 
The adolescents answered the Brazilian versions of the Oral Health Impact Profile (OHIP-14) (Slade, 1997; Soe et al., 2004; Oliveira \& Nadanoysky, 2005) and the Subjective Happiness Scale (SHS) (Pais-Ribeiro, 2012; Medeiros et al., 2014; Ortiz et al., 2021). The OHIP-14 has 14 questions distributed among seen domains. Each question has five scored response options (never $=0$, hardly ever $=1$, occasionally $=2$, fairly often $=3$, and often $=4$ ). The total ranges from 0 to 56 points, with higher scores denoting greater impact (Slade, 1997; Soe et al., 2004; Oliveira \& Nadanoysky, 2005). The SHS is a self-report measure addressing whether the respondent considers himself/herself to be happy or unhappy based on the answer to four statements. There is an increasing scale (1 to 7) for each item, with lower scores denoting less happiness (Pais-Ribeiro, 2012; Medeiros et al., 2014; Ortiz et al., 2021).

TMD was assessed using the Brazilian version of the Research Diagnostic Criteria for Temporomandibular Disorders (RDC/TMD). This instrument is composed of two axes (Franco et al., 2014; Paiva Bertoli et al., 2018). Axis I invlves a clinical evaluation for the classification of the individual in three diagnostic groups: Muscle disorders (myofascial pain and myofascial pain with limited opening), disc displacement (with reduction, without reduction, or without reduction and with limited opening), and joint disorders (arthralgia, osteoarthritis, and osteoarthrosis) (Franco-Micheloni et al., 2014). Axis II is self-administered and has 32 items that assist in a psychosocial assessment of nonspecific physical symptoms, such as pain, generalized anxiety disorder, and signs of depression (absent, moderate, or severe) (Simoen et al., 2020). To evaluate disability and psychological status by RDC/TMD Axis II, it was used scoring graded chronic pain (GPC Scale) and scoring the distress scale items.

During the intraoral clinical examination of the adolescents, the following conditions were also evaluated as possible confounding variables of the association between TMD and OHRQoL: dental caries (Decayed, Missing, and Filled Teeth index [DMFT]) (Whoqol Group, 1995), traumatic dental injuries (Cortes et al., 2002; Andreasen et al., 2018), fluorosis (Dean, 1934), malocclusion (Cardoso et al., 2011; Costa et al., 2011), tooth wear (Lobbezoo et al., 2018), molar incisor hypomineralization (Weerheijm et al., 2003), dental erosion (Vargas-Ferreira et al., 2011), and geographic/fissured tongue (Reamy et al., 2010).

\subsection{Calibration exercise and pilot study}

Two examiners (A.L.P.B. and G.A.F.) underwent training and calibration exercises coordinated by experienced dentists for the use of the clinical indices employed in the data collection process. The examiners received training in theory and practice involving the clinical examination of 28 patients. The Kappa coefficient for inter-examiner agreement regarding the diagnosis of TMD was 0.907. Calibration for dental caries (Whoqol Group, 1995), traumatic dental injury (Cortes et al., 2002; Andreasen et al., 2018), fluorosis (DEAN) (Dean, 1934), malocclusion (DAI) (Cardoso et al., 2011; Costa et al., 2011), tooth wear (Lobbezoo et al., 2018), molar incisor hypomineralization (Weerheijm et al., 2003), dental erosion (Vargas-Ferreira et al., 2011), geographic/fissured tongue (Reamy et al., 2010) was performed (theory and practice) involving the evaluation of photographs. For the Dental Aesthetic Index (DAI), training involved both theory and the use of plaster models. Intra-examiner and inter-examiner Kappa coefficients were $\geq 0.80$ for all indices.

Prior to the data collection procedures, a pilot study was conducted with 10 adolescents to test the proposed methods. The results of the pilot study revealed no need to alter the methods. Therefore, the participants were included in the main study.

\subsection{Data collection}

All data were collected in a single session by researchers who had undergone the training and calibration exercises. The questionnaires were self-administered by the parents/guardians and adolescents. The adolescents were then clinically 
examined in a dental chair under artificial light at the clinic of the UFMG School of Dentistry, using individual protective equipment and a sterile kit containing a mouth mirror and WHO probe.

\subsection{Statistical analyses}

Data analysis was performed with the aid of the Statistical Package for the Social Sciences (SPSS -version 20.0). The OHIP-14 items were dichotomized as "absence of negative impact" (answers of "never" and "hardly ever") or "presence of negative impact" on OHRQoL (answers of "occasionally", "fairly often", and "often") (Oliveira \& Sheiham, 2004; Oliveira et al., 2015). Individuals who answered "occasionally", "fairly often", or "often" to at least one of the OHIP-14 items were considered to have impact on OHRQoL. The same reasoning was employed for the interpretation of the separate domains. The answers to the RDC/TMD were assessed by axis. A positive diagnosis for any of the classifications on Axis I was considered indicative of the presence of TMD. All variables on Axis II were dichotomized (present [moderate and severe classifications] or absent [normalclassification]) (Franco-Micheloni et al., 2014; Simoen et al., 2020).

The data were initially submitted to descriptive statistics (absolute and relative frequencies; mean and standard deviation). Unadjusted and adjusted binary regression models were used to evaluate the association between the dependent variable (OHIP-14: with/without impact) and socioeconomic/demographic characteristics, health-related characteristics, level of happiness, TMD, and other oral conditions. Independent variables with a p-value $\leq 0.20$ in the univariate analysis were incorporated into the multivariate models. The selected variables were tested for the occurrence of multicollinearity. When collinearity was identified between a pair or group of variables, only one was incorporated into the model (based on the theoretical support model). As different diagnoses related to TMD determined by the RDC/TMD exhibited collinearity, five separate multivariate models (each with only one of the possible diagnoses as the independent variable of interest) were run to gain a better understanding of the contribution of the diverse aspects related the impact of TMD on OHRQoL (Any positive diagnosis on Axis I in Model 1, Chronic pain in Model 2, Suggestive signs of depression in Model 3, Nonspecific symptoms including pain in Model 4, Generalized anxiety disorder in Model 5). Wald's backward method was used to generate the final models with adjusted odds ratios (OR) and respective 95 confidence intervals (CI) for the impact on OHRQoL among the categories of independent variables.

Bivariate analyses (Mann-Whitney test, chi-squared test, or Fisher's exact test, depending on thescales and distribution of the variables) were performed to investigate associations between each domain of the OHIP-14 (functional limitation, physical pain, psychological discomfort, physical disability, psychological disability, social disability, and handicap) and the predictor variables. The level of significance on these tests was set at $5 \%(\mathrm{p}<0.05)$.

\section{Results}

With the advent of the COVID-19 pandemic, dental appointments at the University clinic were suspended and data collected was interrupted after finding 105 adolescents between 13 and 18 years of age who met the eligibility criteria, among whom 14.3\% did not return the signed statements of consent (adherence rate: 85.7\%). Among the 90 adolescents who were submitted to all clinical examinations and answered the data collection instruments, 51.15\% $(n=46)$ were girls, mean age was $15.9 \pm 1.7$ years, $73 \%$ were self-declared as black, brown, or indigenous, and $27 \%$ were self-declared as white or yellow. Amongthe parents/guardians, 36\% reported having studied eight years or less, mean age was $39 \pm 12.1$ years, and 30.5\% had a family income of up to the Brazilian monthly minimum wage (corresponding to $\$ 235.95$ in the year of the data collection (2019). The prevalence of TMD in the sample was 44\% (95\% CI: 34 to 55\%).Among the diagnoses on Axis I of the RDC/TMD, the most prevalent was joint disorder (41\%); $15 \%$ were diagnosed with muscle disorder and $12 \%$ were diagnosed with disc 
displacement. On Axis II, signs of depression were the most prevalent disorder (48\%), followed by nonspecific physical symptoms includingpain (47\%), generalized anxiety disorder (43\%), and chronic pain (29\%).

Table 1 displays the prevalence of negative impact on the total OHIP-14 and each domain. A total of $34 \%$ of the adolescents reported a negative impact on OHRQoL. The domain with a great frequency of negative impact was psychological discomfort (28\%), being the main complaints concern with mouth and teeth problems (27.0\%), shame about oral problems $(15.6 \%)$ and having pain in the mouth and teeth (12.2\%). The mean total OHIP-14 score among the adolescents was 8.4 (standard deviation: 8.7 ) and the 25th, 50th, and 75th percentiles were 2, 6, and 12, respectively.

Table 1. Prevalence of negative impact on adolescents OHRQoL, by domain and considering the total OHIP-14 score

\begin{tabular}{ll}
\hline Domain $\boldsymbol{O H I P - 1 4}$ & Prevalence $($ CI 95\%) \\
\hline Functional limitation & $7 \%(1-12)$ \\
Physical pain & $15 \%(7-23)$ \\
Psychological discomfort & $28 \%(18-38)$ \\
Physical disability & $6 \%(1-11)$ \\
Psychological disability & $19 \%(10-27)$ \\
Handicap & $5 \%(0-9)$ \\
Social disability & $-*$ \\
Mean total $O H I P-14$ & $34 \%(24-44)$ \\
\hline
\end{tabular}

*There was no impact for the "Social disability" domain. Source: Authors.

No socioeconomic or demographic variable was associated with OHRQoL in the univariate analysis (Table 2). In contrast, impact on OHRQoL was associated with self-reported general and oral health of theadolescent $(p=0.009$ and 0.012 , respectively), nonspecific signs of pain $(\mathrm{p}=0.018)$ and generalized anxiety disorder $(\mathrm{p}=0.011)($ Table 3$)$, dental caries experience $(\mathrm{p}=0.001)$, reports of toothache $(\mathrm{p}=0.005)$, muscle disorders and disc displacement $(\mathrm{p}=0.026$ and 0.011 , respectively), and chronic pain related to TMD in the previous six months ( $\mathrm{p}=0.004)$ (Table 4$)$.

Table 2. Univariate binary logistic regression model for socioeconomic and demographic variables associated with the negative impact on adolescents' OHRQoL.

\begin{tabular}{|c|c|c|c|}
\hline Predictor variables & $\begin{array}{c}\text { With impact } \\
\text { n }(\%)\end{array}$ & $\begin{array}{c}\text { OHIP-14 } \\
\text { Without impact } \\
\text { n }(\%) \\
\end{array}$ & Value of $p$ \\
\hline \multicolumn{4}{|l|}{ Sex } \\
\hline Male (ref*) & $14(31.8)$ & $30(68.2)$ & \\
\hline Female & $17(37.0)$ & $29(63.0)$ & 0.608 \\
\hline \multicolumn{4}{|l|}{ Skin color (self-declared) } \\
\hline White or yellow (ref) & $5(20.8)$ & $19(79.2)$ & \\
\hline Black, brown or indigenous & $26(40.0)$ & $39(60.0)$ & 0.099 \\
\hline Family income $(\$)-$ mean $\left(\mathrm{SD}^{\#}\right)$ & $1844.12(1096.36)$ & $2622.43(3616.90)$ & 0.450 \\
\hline Adolescent age (in years) - mean (SD) & $15.9(1.9)$ & $15.7(1.6)$ & 0.278 \\
\hline Parents/guardians age (in years) - mean (SD) & $38.1(12.1)$ & $42.4(10.6)$ & 0.147 \\
\hline \multicolumn{4}{|l|}{ Parents/guardians education level } \\
\hline$\leq 8$ years of study (ref) & $13(41.9)$ & $18(58.1)$ & \\
\hline$>8 \mathrm{e} \leq 11$ years of study & $15(34.9)$ & $28(65.1)$ & 0.538 \\
\hline$\geq 12$ years of study & $3(25.0)$ & $9(75.0)$ & 0.309 \\
\hline
\end{tabular}

* Ref: reference; ${ }^{\#}$ SD: Stardard deviation. Source: Authors. 
Table 3. Unadjusted binary logistic regression model for health-related variables associated with the negative impact on adolescents OHRQoL.

\begin{tabular}{|c|c|c|c|}
\hline Predictor variables & $\begin{array}{c}\text { With impact } \\
n(\%)\end{array}$ & $\begin{array}{c}\text { OHIP-14 } \\
\text { Without impact } \\
\text { n }(\%) \\
\end{array}$ & Value of $p$ \\
\hline \multicolumn{4}{|l|}{ General health of the adolescent (self-reported) } \\
\hline Good/Very good (ref*) & $23(29.1)$ & $56(70.9)$ & \\
\hline Regular/Bad/Very bad & $8(72.7)$ & $3(27.3)$ & 0.009 \\
\hline \multicolumn{4}{|l|}{ Oral health of the adolescent (self-reported) } \\
\hline Good/Very good (ref) & $16(25.8)$ & $46(74.2)$ & \\
\hline Regular/Bad/Very bad & $15(53.6)$ & $13(46.4)$ & 0.012 \\
\hline \multicolumn{4}{|l|}{ Sleep quality (report of parents/guardians) } \\
\hline Very good (ref) & $8(36.4)$ & $14(63.6)$ & \\
\hline Good & $15(30.6)$ & $34(69.4)$ & 0.632 \\
\hline Regular & $8(47.1)$ & $9(52.9)$ & 0.502 \\
\hline \multicolumn{4}{|l|}{ Adolescent's sleep hours (report of parents/guardians) } \\
\hline$\leq 8$ hours a night $($ ref $)$ & $19(34.5)$ & $36(65.5)$ & \\
\hline$>8$ hours a night & $12(36.4)$ & $21(63.6)$ & 0.863 \\
\hline Subjective Happiness Scale (SHS) - mean $\left(\mathrm{SD}^{\#}\right)$ & $17.7(4.1)$ & $18.5(3.3)$ & 0.326 \\
\hline \multicolumn{4}{|l|}{ Chronic pain (RDC/TMD, Axis II) } \\
\hline Absent (ref) & $16(25.0)$ & $48(75.0)$ & \\
\hline Present & $15(57.7)$ & $11(42.3)$ & 0.004 \\
\hline \multicolumn{4}{|l|}{ Signs of depression (RDC/TMD, Axis II) } \\
\hline Absent (ref) & $12(26.1)$ & $34(73.9)$ & \\
\hline Present & $19(44.2)$ & $24(55.8)$ & 0.076 \\
\hline \multicolumn{4}{|l|}{$\begin{array}{l}\text { Nonspecific symptoms including pain (RDC/TMD, } \\
\text { Axis II) }\end{array}$} \\
\hline Absent (ref) & $11(23.4)$ & $36(76.6)$ & \\
\hline Present & $20(47.6)$ & $22(52.4)$ & 0.018 \\
\hline \multicolumn{4}{|l|}{ Generalized anxiety disorder (RDC/TMD, Axis II) } \\
\hline Absent (ref) & $12(23.5)$ & $39(76.5)$ & \\
\hline Present & $19(50.0)$ & $19(50.0)$ & 0.011 \\
\hline
\end{tabular}

* Ref: reference; ${ }^{\#}$ SD: Stardard deviation. Source: Authors. 
Table 4. Univariate binary logistic regression model for variables related to oral conditions associated with the negative impact on OHRQoL of adolescents.

\begin{tabular}{|c|c|c|c|}
\hline Predictor variables & $\begin{array}{c}\text { With impact } \\
\text { n }(\%)\end{array}$ & $\begin{array}{c}\text { OHIP-14 } \\
\text { Without impact } \\
\text { n }(\%) \\
\end{array}$ & Value of $p$ \\
\hline \multicolumn{4}{|l|}{ TMD* } \\
\hline Absent (ref) & $13(26.0)$ & $37(74.0)$ & \\
\hline Present & $18(45.0)$ & $22(55.0)$ & 0.062 \\
\hline \multicolumn{4}{|l|}{ Muscle disorders } \\
\hline Absent $\left(\right.$ ref $\left.^{\&}\right)$ & $21(28.4)$ & $53(71.6)$ & \\
\hline Present & $8(61.5)$ & $5(38.5)$ & 0.026 \\
\hline \multicolumn{4}{|l|}{ Disc displacement } \\
\hline Absent (ref) & $23(29.9)$ & $54(70.1)$ & \\
\hline Present & $8(72.7)$ & $3(27.3)$ & 0.011 \\
\hline \multicolumn{4}{|l|}{ Joint disorders } \\
\hline Absent (ref) & $16(30.2)$ & $37(69.8)$ & \\
\hline Present & $15(40.5)$ & $22(59.5)$ & 0.311 \\
\hline \multicolumn{4}{|l|}{ Toothache (self-reported) } \\
\hline No (ref) & $1(4.3)$ & $22(95.7)$ & \\
\hline Yes & $30(46.9)$ & $34(53.1)$ & 0.005 \\
\hline Dental caries experience (DMFT) - mean $\left(\mathrm{SD}^{\#}\right)$ & $4.26(3.27)$ & $1.95(2.45)$ & 0.001 \\
\hline \multicolumn{4}{|l|}{ Tooth wear } \\
\hline Absent (ref) & $21(33.9)$ & $41(66.1)$ & \\
\hline Present & $10(35.7)$ & $18(64.3)$ & 0.865 \\
\hline \multicolumn{4}{|l|}{ Dental erosion } \\
\hline Absent (ref) & $29(34.5)$ & $55(65.5)$ & \\
\hline Present & $2(40.0)$ & $3(60.0)$ & 0.803 \\
\hline \multicolumn{4}{|l|}{ Fluorosis } \\
\hline Absent (ref) & $18(38.3)$ & $29(61.7)$ & \\
\hline Present & $13(30.2)$ & $30(69.8)$ & 0.422 \\
\hline \multicolumn{4}{|l|}{ Molar incisor hypomineralization (MIH) } \\
\hline Absent (ref) & $31(35.2)$ & $57(64.8)$ & \\
\hline Present & $0(0.0)$ & $2(100.0)$ & 0.999 \\
\hline \multicolumn{4}{|l|}{ Traumatic dental injury } \\
\hline Absent (ref) & $25(33.3)$ & $50(66.7)$ & \\
\hline Present & $3(37.5)$ & $5(62.5)$ & 0.813 \\
\hline \multicolumn{4}{|l|}{ Malocclusion } \\
\hline No $(\mathrm{DAI} \leq 25)(\mathrm{ref})$ & $11(36.7)$ & $19(63.3)$ & \\
\hline Yes $(\mathrm{DAI} \geq 26)$ & $20(33.3)$ & $40(66.7)$ & 0.754 \\
\hline \multicolumn{4}{|l|}{ Geographic tongue } \\
\hline No (ref) & $28(33.3)$ & $56(66.7)$ & \\
\hline Yes & $3(50.0)$ & $3(50.0)$ & 0.414 \\
\hline \multicolumn{4}{|l|}{ Fissured tongue } \\
\hline No (ref) & $15(30.0)$ & $35(70.0)$ & \\
\hline Yes & $16(40.0)$ & $24(60.0)$ & 0.322 \\
\hline
\end{tabular}

*Presence of any diagnosis obtained by Axis I of the RDC / TMD (muscle disorders, disc displacement or joint disorders);

\&Ref: reference; \# SD: \#Stardard deviation. Source: Authors.

The adjusted regression models (Table 5) showed associations between practically all TMD diagnoses evaluated and OHRQL. Adolescents with muscle and/or joint disorders and/or disc displacement were 4.13-fold (95\% CI: 1.08 to 15.80) more likely to have negative impact on OHRQoL (Model 1). Those with chronic pain, nonspecific symptoms including pain, and generalized anxiety disorder were 4.08-fold (95\% CI: 1.01 to 16.53; Model 2), 5.48-fold 95\% CI: 1.21 to 24.73; Model 4), and 10.50-fold (95\% CI: 2.50 to 44.14; Model 5) more likely to have negative impact on OHRQoL in comparison to those who did not exhibit these signs and symptoms. On the other hand, the study was unable to detect an association between suggestive 
signs of depression and negative impact on OHRQoL (Model 3). Caries experience (DMFT index) was kept associated with negative impact on OHRQoL after adjustments in all models.

Associations between each OHIP-14 domain and sociodemographic, health-related, and clinical variables are displayed in Table 6. Adolescents with younger parents/guardians $(\mathrm{p}=0.046)$ and those with chronic pain related to TMD in the previous six months $(\mathrm{p}=0.007)$, muscle disorders $(\mathrm{p}=0.022)$, and nonspecific symptoms including pain $(\mathrm{p}=0.009)$ reported a greater frequency of impact on the "functionallimitation" domain. The prevalence of impact on the "physical pain" domain was associated with muscle disorders ( $p=0.025)$, reports of toothache $(\mathrm{p}=0.009)$, and all diagnoses on Axis II of the RDC/TMD ( $p<0.05$ ), except sings of depression. These same variables were associated with an impact on the "psychological discomfort" domain, the latter was also associating with the dental caries experience. Onlydental erosion exerted an impact on the "physical disability" domain ( $\mathrm{p}=0.036)$. Adolescents who considered their general and oral health to be fair or poor $(\mathrm{p}=$ 0.030 and 0.001 , respectively) and those withchronic pain $(\mathrm{p}=0.034)$, disc displacement $(\mathrm{p}=0.033)$, signs of depression $(\mathrm{p}=$ 0.041), generalized anxiety disorder $(p=0.041)$, dental caries experience $(p=0.001)$ and reports of toothache $(p=0.004)$ reported impact on the "psychological disability" domain. 
Table 5. Multiple binary logistic regression models for the presence of negative impact on OHRQoL.

\begin{tabular}{|c|c|c|c|c|c|}
\hline \multirow[t]{2}{*}{ Variables } & \multicolumn{5}{|c|}{ Impact on Oral Health-Related Quality of Life-OHIP-14 } \\
\hline & $\begin{array}{c}\text { Model 1 } \\
\text { OR adjusted (CI 95\%) }\end{array}$ & $\begin{array}{c}\text { Model } 2 \\
\text { OR adjusted (CI 95\%) }\end{array}$ & $\begin{array}{c}\text { Model } 3 \\
\text { OR adjusted (CI 95\%) }\end{array}$ & $\begin{array}{c}\text { Model } 4 \\
\text { OR adjusted (CI 95\%) }\end{array}$ & $\begin{array}{c}\text { Model } 5 \\
\text { OR adjusted (CI 95\%) }\end{array}$ \\
\hline TMD (present of TMD*) & $4.13(1.08-15.8)$ & - & $=$ & - & - \\
\hline Dental caries experience (DMFT) & $1.34(1.08-1.66)$ & $1.32(1.07-1.62)$ & $1.29(1.04-1.58)$ & $1.37(1.09-1.72)$ & $1.44(1.14-1.82)$ \\
\hline Toothache (self-reported) & $11.09(1.05-116.7)$ & $10.47(0.96-113.9)$ & $11.27(0.90-140.9)$ & $7.25(0.40-132.32)$ & - \\
\hline $\begin{array}{l}\text { Oral health of the adolescent } \\
\text { (self-reported) }\end{array}$ & - & - & $2.62(0.71-9.66)$ & $3.11(0.77-12.55)$ & - \\
\hline $\begin{array}{l}\text { Chronic pain } \\
\text { (RDC/TMD, Axis II) }\end{array}$ & - & $4.08(1.01-16.53)$ & - & $\cdot$ & - \\
\hline Signs of depression (RDC/TMD, Axis II) & - & - & $2.15(0.59-7.86)$ & - & - \\
\hline $\begin{array}{l}\text { Nonspecific symptoms including pain } \\
\text { (RDC/TMD, Axis II) }\end{array}$ & - & - & - & $5.48(1.21-24.73)$ & - \\
\hline $\begin{array}{l}\text { Generalized anxiety disorder } \\
\text { (RDC/TMD, Axis II) }\end{array}$ & $\cdot$ & $\cdot$ & - & - & $10.50(2.50-44.14)$ \\
\hline
\end{tabular}

* Presence of any diagnosis obtained by Axis I of the RDC/TMD (muscle disorders, disc displacement or joint disorders)

Variables included in all models: DMFT; Toothache; Oral health of the adolescent (self-reported).

Source: Authors. 
Research, Society and Development, v. 10, n. 14, e379101421981, 2021

(CC BY 4.0) | ISSN 2525-3409 | DOI: http://dx.doi.org/10.33448/rsd-v10i14.21981

Table 6. Bivariate analysis for variables associated with the presence of impact in the OHIP-14 domains.

\begin{tabular}{|c|c|c|c|c|c|c|}
\hline Predictor variables & $\begin{array}{l}\text { Functional } \\
\text { limitation }\end{array}$ & $\begin{array}{c}\text { Physical } \\
\text { pain }\end{array}$ & $\begin{array}{c}\text { Psychological } \\
\text { discomfort }\end{array}$ & $\begin{array}{r}\text { Physical } \\
\text { disability }\end{array}$ & $\begin{array}{c}\text { Psychological } \\
\text { disability }\end{array}$ & Handicap \\
\hline Sex & $\mathrm{p}=1.000^{\mathfrak{f}}$ & $\mathrm{p}=0.691^{*}$ & $\mathrm{p}=0.521^{*}$ & $\mathrm{p}=0.424^{\mathfrak{f}}$ & $\mathrm{p}=0.711^{*}$ & $\mathrm{p}=0.429^{\mathfrak{f}}$ \\
\hline Skin color (self-reported) & $\mathrm{p}=0.185^{\mathfrak{f}}$ & $\mathrm{p}=0.332^{\mathrm{f}}$ & $\mathrm{p}=0.135^{*}$ & $\mathrm{p}=0.183^{£}$ & $\mathrm{p}=0.140^{f}$ & $\mathrm{p}=0.185^{\mathfrak{f}}$ \\
\hline Family income $(\$)$ & $\mathrm{p}=0.838^{\#}$ & $\mathrm{p}=0.763^{\#}$ & $\mathrm{p}=0.748^{\#}$ & $\mathrm{p}=0.376^{\#}$ & $\mathrm{p}=0.915^{\#}$ & $\mathrm{p}=0.273^{\#}$ \\
\hline Adolescent age (in years) & $\mathrm{p}=0.601^{\#}$ & $\mathrm{p}=0.861^{\#}$ & $\mathrm{p}=0.209^{\#}$ & $\mathrm{p}=0.867^{\#}$ & $\mathrm{p}=0.099^{\#}$ & $\mathrm{p}=0.259^{\#}$ \\
\hline Parents/guardians age (in years) & $\mathrm{p}=0.046^{\#}$ & $\mathrm{p}=0.886^{\#}$ & $\mathrm{p}=0.247^{\#}$ & $\mathrm{p}=0.783^{\#}$ & $\mathrm{p}=0.740^{\#}$ & $\mathrm{p}=0.815^{\#}$ \\
\hline Parents/guardians education level & $\mathrm{p}=0.587 *$ & $\mathrm{p}=0.814^{*}$ & $\mathrm{p}=0.922 *$ & $\mathrm{p}=0.982 *$ & $\mathrm{p}=0.223^{*}$ & $\mathrm{p}=0.587 *$ \\
\hline Number of residents in the house & $\mathrm{p}=0.486^{\#}$ & $\mathrm{p}=0.162^{\#}$ & $\mathrm{p}=0.291^{\#}$ & $\mathrm{p}=0.167^{\#}$ & $\mathrm{p}=0.199^{\#}$ & $\mathrm{p}=0.266^{\#}$ \\
\hline Number of bathrooms (report of parents/guardians) & $\mathrm{p}=0.353^{\#}$ & $\mathrm{p}=0.866^{\#}$ & $\mathrm{p}=0.879^{\#}$ & $\mathrm{p}=0.746^{\#}$ & $\mathrm{p}=0.299^{\#}$ & $\mathrm{p}=0.947^{\#}$ \\
\hline General health of the adolescent (self-reported) & $\mathrm{p}=0.155^{\mathfrak{1}}$ & $\mathrm{p}=0.070^{£}$ & $\mathrm{p}=0.067^{£}$ & $\mathrm{p}=0.558^{£}$ & $\mathbf{p}=\mathbf{0 . 0 3 0} 0^{£}$ & $\mathrm{p}=0.155^{£}$ \\
\hline Oral health of the adolescent (self-reported) & $\mathrm{p}=1.000^{\mathrm{f}}$ & $\mathrm{p}=0.754^{£}$ & $\mathrm{p}=0.215^{*}$ & $\mathrm{p}=0.374^{£}$ & $\mathrm{p}=0.001 *$ & $\mathrm{p}=1.000^{f}$ \\
\hline Sleep quality (report of parents/guardians) & $\mathrm{p}=0.284^{*}$ & $\mathrm{p}=0.565^{*}$ & $\mathrm{p}=0.620^{*}$ & $\mathrm{p}=0.851^{*}$ & $\mathrm{p}=0.372 *$ & $\mathrm{p}=0.647^{*}$ \\
\hline Adolescent's sleep hours (report of parents/guardians) & $\mathrm{p}=0.192^{\mathrm{f}}$ & $\mathrm{p}=0.823^{*}$ & $\mathrm{p}=0.428^{*}$ & $\mathrm{p}=0.669^{\mathrm{f}}$ & $\mathrm{p}=0.834^{*}$ & $\mathrm{p}=1.000^{f}$ \\
\hline Subjective Happiness Scale (SHS) (total score) & $\mathrm{p}=0.916^{\#}$ & $\mathrm{p}=0.968^{\#}$ & $\mathrm{p}=0.683^{\#}$ & $\mathrm{p}=0.256^{\#}$ & $\mathrm{p}=0.590^{\#}$ & $\mathrm{p}=0.138^{\#}$ \\
\hline Muscle disorders ${ }^{\mathrm{I}}$ & $\mathrm{p}=0.022^{\mathrm{f}}$ & $\mathrm{p}=0.025^{\mathfrak{\varepsilon}}$ & $\mathrm{p}=0.005^{£}$ & $\mathrm{p}=1.000^{\mathrm{f}}$ & $\mathrm{p}=0.058^{f}$ & $\mathrm{p}=0.218^{£}$ \\
\hline Disc displacement $^{\mathrm{I}}$ & $\mathrm{p}=0.161^{\mathfrak{f}}$ & $\mathrm{p}=0.377^{\mathfrak{1}}$ & $\mathrm{p}=0.070^{\mathfrak{f}}$ & $\mathrm{p}=0.165^{\mathfrak{1}}$ & $\mathrm{p}=\mathbf{0 . 0 3 3 ^ { \mathfrak { E } }}$ & $\mathrm{p}=0.161^{\mathfrak{f}}$ \\
\hline Joint disorders ${ }^{\mathrm{I}}$ & $\mathrm{p}=0.224^{\mathfrak{f}}$ & $\mathrm{p}=0.212^{*}$ & $\mathrm{p}=0.165^{*}$ & $\mathrm{p}=1.000^{f}$ & $\mathrm{p}=0.271^{*}$ & $\mathrm{p}=0.687^{\mathfrak{f}}$ \\
\hline $\mathrm{TMD}^{\&}$ & $\mathrm{p}=0.085^{£}$ & $\mathrm{p}=0.123 *$ & $\mathrm{p}=0.055^{*}$ & $\mathrm{p}=0.402^{£}$ & $\mathrm{p}=0.062 *$ & $\mathrm{p}=0.400^{\mathfrak{f}}$ \\
\hline Chronic pain & $\mathrm{p}=0.007^{£}$ & $\mathbf{p}=0.004^{£}$ & $\mathbf{p}=0.003^{*}$ & $\mathrm{p}=1.000^{£}$ & $\mathbf{p}=\mathbf{0 . 0 3 4} *$ & $\mathrm{p}=0.350^{£}$ \\
\hline Signs of depression ${ }^{\mathrm{II}}$ & $\mathrm{p}=0.103^{£}$ & $\mathrm{p}=0.058^{*}$ & $\mathrm{p}=0.054 *$ & $\mathrm{p}=0.678^{£}$ & $\mathrm{p}=0.041 *$ & $\mathrm{p}=0.678^{£}$ \\
\hline Nonspecific symptoms including pain ${ }^{\mathrm{II}}$ & $\mathrm{p}=0.009^{£}$ & $\mathbf{p}=0.001 *$ & $\mathrm{p}=0.016^{*}$ & $\mathrm{p}=1.000^{£}$ & $\mathrm{p}=0.108^{*}$ & $\mathrm{p}=0.415^{£}$ \\
\hline Generalized anxiety disorder ${ }^{\mathrm{II}}$ & $\mathrm{p}=0.080^{\mathfrak{f}}$ & $\mathrm{p}=0.002 *$ & $\mathrm{p}=0.013^{*}$ & $\mathrm{p}=1.000^{£}$ & $\mathrm{p}=0.041 *$ & $\mathrm{p}=0.395^{£}$ \\
\hline Dental caries experience (DMFT) & $\mathrm{p}=0.308^{\#}$ & $\mathrm{p}=0.131^{\#}$ & $\mathbf{p}=\mathbf{0 . 0 3 7}^{\#}$ & $\mathrm{p}=0.306^{\#}$ & $\mathbf{p}=\mathbf{0 . 0 0 1}^{\#}$ & $\mathrm{p}=0.876^{\#}$ \\
\hline Traumatic dental injury (clinical examination) & $\mathrm{p}=1.000^{f}$ & $\mathrm{p}=0.608^{£}$ & $\mathrm{p}=0.412^{\mathfrak{f}}$ & $\mathrm{p}=1.000^{£}$ & $\mathrm{p}=1.000^{f}$ & $\mathrm{p}=1.000^{f}$ \\
\hline Malocclusion (DAI) & $\mathrm{p}=0.173^{\mathrm{f}}$ & $\mathrm{p}=1.000^{£}$ & $\mathrm{p}=0.775^{*}$ & $\mathrm{p}=0.172^{\mathrm{f}}$ & $\mathrm{p}=0.128^{*}$ & $\mathrm{p}=0.659^{\mathrm{f}}$ \\
\hline Dental erosion (clinical examination) & $\mathrm{p}=0.301^{£}$ & $\mathrm{p}=0.181^{£}$ & $\mathrm{p}=0.620^{£}$ & $\mathrm{p}=\mathbf{0 . 0 3 6}^{\mathfrak{E}}$ & $\mathrm{p}=0.242^{£}$ & $\mathrm{p}=0.301^{£}$ \\
\hline Molar incisor hypomineralization (MIH) (clinical examination) & $\mathrm{p}=1.000^{£}$ & $\mathrm{p}=1.000^{£}$ & $\mathrm{p}=1.000^{£}$ & $\mathrm{p}=1.000^{£}$ & $\mathrm{p}=1.000^{£}$ & $\mathrm{p}=1.000^{£}$ \\
\hline Tooth wear (clinical examination) & $\mathrm{p}=0.661^{£}$ & $\mathrm{p}=1.000^{\mathrm{f}}$ & $\mathrm{p}=0.764 *$ & $\mathrm{p}=0.663^{£}$ & $\mathrm{p}=0.679 *$ & $\mathrm{p}=1.000^{f}$ \\
\hline Fluorosis (clinical examination) & $\mathrm{p}=0.420^{£}$ & $\mathrm{p}=0.499 *$ & $\mathrm{p}=0.327 *$ & $\mathrm{p}=0.678^{£}$ & $\mathrm{p}=0.636^{*}$ & $\mathrm{p}=1.000^{\mathrm{f}}$ \\
\hline Fissured tongue (clinical examination) & $\mathrm{p}=0.689^{£}$ & $\mathrm{p}=0.338 *$ & $\mathrm{p}=0.983 *$ & $\mathrm{p}=1.000^{\mathfrak{f}}$ & $\mathrm{p}=0.434 *$ & $\mathrm{p}=1.000^{\mathfrak{f}}$ \\
\hline Geographic tongue (clinical examination) & $\mathrm{p}=1.000^{f}$ & $\mathrm{p}=1.000^{\mathrm{f}}$ & $\mathrm{p}=1.000^{f}$ & $\mathrm{p}=1.000^{f}$ & $\mathrm{p}=1.000^{f}$ & $\mathrm{p}=1.000^{f}$ \\
\hline Toothache (self-reported) & $\mathrm{p}=0.334^{£}$ & $\mathrm{p}=0.009^{£}$ & $\mathrm{p}=0.002 *$ & $\mathrm{p}=0.186^{£}$ & $p=0.004^{\mathfrak{f}}$ & $\mathrm{p}=0.334^{£}$ \\
\hline
\end{tabular}

*Persons Chi-square; ${ }^{\mathfrak{f}}$ Fisher's exact; ${ }^{\text {M Mann-Whitney test }}$

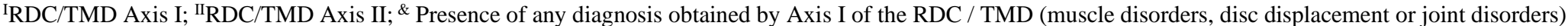

There was no impact report for the "Social disability" domain, which is why it is not shown in the table. 
Research, Society and Development, v. 10, n. 14, e379101421981, 2021

(CC BY 4.0) | ISSN 2525-3409 | DOI: http://dx.doi.org/10.33448/rsd-v10i14.21981

\section{Discussion}

The present study estimated the negative impact of signs and symptoms of TMD on OHRQoL in Brazilian adolescents considering their general and oral health as well as psychological, socioeconomic, and demographic characteristics. The impact on OHRQoL is a complex phenomenon influenced by diverse physical and emotional aspects of general and oral health. The main findings were the high prevalence of TMD among the adolescents and its negative impact (along with variables of the psychological axis [chronic pain and anxiety)] on OHRQoL. Approximately one-third of the adolescents reported negative impacts on OHRQoL, with a mean OHIP-14 score of 8.4. Previous studies conducted with Brazilian adolescents report similar findings (Colussi et al., 2017; Aimée et al., 2017).

The physical pain domain is considered the most important in the measurement of OHRQoL in adolescents and the domain with the highest prevalence of impact in previous studies (Reamy et al., 2010; Aimée et al., 2017). In the present investigation, however, greater impacts were found on the psychological discomfort and psychological disability domains than physical pain domain, which is similar to data described in a previous study involving Brazilian adolescents (Keles et al., 2018). This finding may be explained by the fact that adolescence is a period of emotional, pubertal, psychological, and social maturation, when individuals are more vulnerable to the emergence of psychopathology, with increased emotional intensity and immature cognitive control (Dahl \& Gunnar, 2009; Crone \& Dahl, 2012; Cservenka et al., 2015).

The prevalence of signs and symptoms of TMD among the adolescents in the present study was 44\%, which is slightly higher than the rate reported in the literature for Brazilian adolescents (40\%) (Paiva Bertoli et al., 2018). Regarding the different diagnoses of TMD, the prevalence of joint disorders was higher in the present study. In contrast, Paiva Bertoli et al. (2018) found a higher prevalence of muscle disorders. Differences in the prevalence of TMD in the literature occur due to the diversity of the sample characteristics and the use of different diagnostic instruments (Sena et al., 2013). To avoid the risk of bias, a recognized, validated instrument was used for the diagnosis of TMD in the present study, which also enables comparisons with the results of other studies addressing this disorder (Franco-Micheloni et al., 2014).

Adolescents with TMD were fourfold more likely to have a negative impact on OHRQoL compared to those without TMD. Barbosa et al. (2016) report similar results in a study involving children and adolescents (8-14 years of age) using the Child Perceptions Questionnaires (CPQ) for the measurement of negative impact on OHRQoL (Barbosa et al., 2016). Moreover, a poorer perception of OHRQoL was associated with diagnoses of muscle disorders, disc displacement, chronic pain, and nonspecific symptoms including pain and generalized anxiety disorder. These findings are compatible with those reported by Paulino et al. (2018), who found that TMD exerted a negative impact on OHRQoL among Brazilian adolescents and young adults (Paulino et al., 2018).

The individual diagnoses of Axis I of the RDC/TMD exerted impacts on the functional limitation, physical pain, psychological discomfort and psychological disability domains of the OHIP-14, whereas discdisplacement was only associated with psychological disability, muscle disorders were associated were functional limitation, physical pain, and psychological discomfort. Such findings were expected, as these diagnoses cause pain, mouth opening limitation, and sounds during the movements of the temporomandibular joint (Bitiene et al., 2018; Paiva Bertoli et al., 2018). The associations with the OHIP14 domains underscores the disabling role of signs and symptoms of TMD and their influence on OHRQoL, which is compatible with data described in the literature (Resende et al., 2011; Lemos et al., 2015; Bitiniene et al., 2018; Paulino et al., 2018).

Pain is the most common symptom of TMD (Bitiene et al., 2018). In the present investigation, approximately onethird of the adolescents experienced chronic pain and $47 \%$ had nonspecific symptoms including pain due to TMD in the 
previous six months. Adolescents with a report of chronic pain were fourfold more likely to report a negative impact on OHRQoL and those diagnosed with nonspecific symptoms were nearly fivefoldmore likely to report an impact. Constant pain can lead to the development of psychological conditions, such as depression, stress, and anxiety, due to the difficulty in performing activities of daily living and maintaining interpersonal relationships (Cioffi et al., 2014; Silva et al., 2017; Bitiniene et al., 2018).

In the study, approximately half of the individuals had signs of depression and generalized anxiety disorder (43\%) diagnosed by RDC/TMD. Furthermore, those diagnosed with generalized anxiety disorder were 10-fold more likely to have a negative impact on OHRQoL. Previous studies have described an increased prevalence of mental disorders in individuals with TMD (La Torre et al., 2018; Simoen et al., 2020; Resende et al., 2020), these disorders, in turn, could affect quality of life (Sawyer et al., 2002; RavensSieberer et al., 2008; Bronsard et al., 2013). Some studies also indicate that signs and symptoms of depression and anxiety are risk factors for the initiation (Slade et al., 1997; Filingim et al., 2013; Simoen et al., 2020), installation (Velly et al., 2011; Dunn et al., 2011; Simoen et al., 2020), and establishment of a more difficult response to the treatment of pain in cases of TMD (Gardea et al., 2001; Turner et al., 2006; Barbosa et al., 2011), indirectlycontributing to a greater negative impact on quality of life. This dual direct/indirect pathway may explain the large effect that we found on OHRQoL and, along with the high prevalence of these conditions, underscores the importance of the psychosocial assessment of patients diagnosed with TMD in a multidisciplinary approach. The screening of patients with these conditions that have a known impact on quality of life would also provide information related to the prognosis with regards to the persistence of pain and the response to treatment for TMD (Barbosa et al., 2011; Natu et al., 2018).

Dental caries was another clinical condition that exerted a negative impact on OHRQoL. Divergences are found in the literature on the association between dental caries and OHRQoL due to the different age groups analyzed, differences in the prevalence and severity of caries in distinct populations, and differences in the methods of analysis (Paula et al., 2012; Oliveira et al., 2015). In the present investigation, as occurred in a previous study involving Brazilian adolescents (Oliveira et al., 2015); individuals with higher DMFT scores were nearly twofold morelikely to have negative impact on OHRQoL after the adjustments for the other variables in all multivariate models. Moreover, toothache was strongly associated with a poorer OHRQoL. This finding is compatible with the results of a systematic review and meta-analysis, which reported that children and adolescent withdental pain are more likely to experience a negative impact on OHRQoL (Barasoul et al., 2020).

Self-rated general health and oral health represent how adolescents perceive their health and were strongly associated with OHRQoL. Oliveira et al. (2015) reported similar findings in a study involving incarcerated adolescents. These results demonstrate the influence that self-perceived conditions, such as esthetics and pain, can have on OHRQoL (Oliveira et al., 2015). Adolescents who rated their oral health as fair/poor/very poor were approximately fourfold more likely to have an impact on OHRQoL than those who rated their oral health as good/very good. Both self-reports were associated with the psychological disability domain of the OHIP-14. We opted not to include self-rated general health in the adjusted models because this variable exhibited collinearity with self-perceived oral health.

To control for possible confounding factors in the association between TMD and OHRQoL, we analyzed not only self-rated general and oral health, toothache, and dental caries, but also sociodemographic and health-related characteristics, the habits of the adolescents, and other oral conditions. These variables were included based on theoretical references: (Oliveira \& Sheiham, 2004; Michel-Crosato et al., 2005; Al-Omiri et al., 2006; Biazevic et al., 2008; Moreno et al., 2009; Reamy et al., 2010; Vargas-Ferreira et al., 2011; Miettinen et al., 2012; Oliveira et al., 2015; Tuchtenhagen et al., 2015; Mangold et al., 2016; Rosa et al., 2016; Li \& Bernabé, 2016; Dantas-Neta et al., 2016; Sun et al., 2017; Colussi et al., 2017; Blanco Aguilera et al., 2017; Bitiniene et al., 2018; Lopez et al., 2019; Barasoul et al., 2020). However, we found no associations between these conditions and the 
negative impact on OHRQoL. This may have occurred due to the particularities of the present sample, such as difference in age and number of participants.

The present study has limitations that should be considered: Data collection was interrupted due to the COVID-19 pandemic in 105 adolescents who represented a non-population-based convenience sample recruited from a dental clinic, which likely a higher prevalence of TMD had compared to the general population. However, this limitation did not impede us from identifying the association between different diagnoses of TMD and OHRQoL, which was our main objective. Another limitation regards the cross-sectional design, which does not enable the establishment of cause-and-effect relationships between variables.

This study also has strong points. We used reliable, validated instruments for our main variables. We examined clinical conditions that could be considered confounding factors in the association of interest, using established indices, following a careful calibration exercise, and with the entire support of a dental office. We have also subjectively assessed aspects related to general and oral health, and considered a large gamut of socioeconomic and demographic variables. These procedures enabled us to have a broader view of aspects that influence OHRQoL in adolescents and enhanced the reliability of our results, which corroborate the current literature, contributing to the understanding of the impact of TMD on the quality of life of adolescents. The findings of this study can assist in preparing dentists and pediatric dentists for the diagnosis of TMD and assessment of the likelihood of developing the disorder in this phase as well as minimizing its negative impact on the quality of life of adolescents. However, future studies should advance in investigating the impact of multiple simultaneous diagnoses of TMD on the quality of life of adolescents, in a larger and representative population-based sample to ensure adequate power to identify all possibly associations.

\section{Conclusion}

TMD was one of the orofacial conditions that most consistently exerted negative impact on the OHRQoL of the adolescents. Besides clinical diagnosis, variables of the psychological axis, such as chronic pain and anxiety, were associated with negative impact on OHRQoL even after adjusting for control variables.

\section{Acknowledgments}

This study was funded by Universidade Federal de Minas Gerais (UFMG) and the following Brazilian fostering agencies: Coordenação de Aperfeiçoamento de Pessoal de Nível Superior (CAPES [Coordination for the Advancement of Higher Education Personnel]), Conselho Nacional de Desenvolvimento Científico e Tecnológico (CNPQ [National Council of Scientific and Technological Development]), and Fundação de Amparo à Pesquisa do Estado de Minas Gerais (FAPEMIG [State of Minas Gerais Research Assistance Foundation]).

\section{References}

Aimée, N. R., Van Wijk, A. J., Maltz, M., Varjão, M. M., Mestrinho, H. D., \& Carvalho, J. C. (2017). Dental caries, fluorosis, oral health determinants, and quality of life in adolescents. Clinical Orallnvestigations, 21(5), 1811-1820. 10.1007/s00784-016-1964-3

Al-Khotani, A., Naimi-Akbar, A., Albadawi, E., Ernberg, M., Hedenberg-Magnusson, B., \& Christidis, N. (2016). Prevalence of diagnosed temporomandibular disorders among Saudi Arabian childrenand adolescents. The Journal of Headache and Pain, 17(1), 41-52. 10.1186/s10194-016-0642-9

Al-Omiri, M. K., Lamey, P. J., \& Clifford, T. (2006). Impact of tooth wear on dailyliving. The International Journal of Prosthodontics, 19(6), 601-5.

Andreasen, J. O., Andreasen, F. M., \& Andersson, L. (2018). Textbook and color atlas oftraumatic injuries to the teeth. (5a ed.), John Wiley \& Sons; 2018. 
Research, Society and Development, v. 10, n. 14, e379101421981, 2021

(CC BY 4.0) | ISSN 2525-3409 | DOI: http://dx.doi.org/10.33448/rsd-v10i14.21981

Barbosa, T. S., Gaviao, M. B., Castelo, P. M., \& Leme, M. S. (2016). Factors associated withoral health-related quality of life in children and preadolescents: a cross-sectional study. Oral Health and Preventive Dentistry, 14(2), 137-48. 10.3290/j.ohpd.a35301

Barbosa, T. S., Leme, M. S., Castelo, P. M., \& Gavião, M. B. D. (2011). Evaluating oral health- related quality of life measure for children and preadolescents with temporomandibular disorder. Health Quality of Life Outcomes, 9(1), 32-44. 10.1186/1477-7525-9-32.

Barasuol, J. C., Santos, P. S., Moccelini, B. S., Magno, M. B., Bolan, M., Martins-Júnior, P. A., \& Cardoso, M. (2020). Association between dental pain and oral health-related quality of life in children and adolescents: A systematic review and meta-analysis. Community Dentistry and Oral Epidemioligy, 48(4), 257263. $10.1111 /$ cdoe. 12535

Biazevic, M. G. H., Rissotto, R. R., Michel-Crosato, E., Mendes, L. A., \& Mendes, M. O. A. (2008). Relationship between oral health and its impact on quality of life among adolescents. Brazilian Oral Research, 22(1), 36-42. 10.1590/s1806-83242008000100007

Bitiniene, D., Zamaliauskiene, R., Kubilius, R., Leketas, M., Gailius, T., \& Smirnovaite, K. (2018). Quality of life in patients with temporomandibular disorders. A systematic review. Stomatologija, 20(1), 3-9.

Blanco-Aguilera, A., Blanco-Aguilera, E., Serrano-del-Rosal, R., Biedma-Velázquez, L., Rodriguez-Torronteras, A., Segura-Saint-Gerons, R., \& BlancoHungria, A. (2017). Influence of clinical and psychological variables upon the oral health-related quality of life in patients with temporomandibular disorders. Medicina Oral, Patologia Oral, Cirurgia Bucal, 22(6), e669. 10.4317/medoral.21746

Bont LG, Dijkgraaf LC, \& Stegenga B. Epidemiology and natural progression of articular temporomandibular disorders. Oral Surgery, Oral Medicine, Oral Pathology, Oral Radiology and endodontics, 1997; 83(1), 72-76. 10.1016/s1079-2104(97)90094-9.

Bronsard, G., Lançon, C., Loundou, A., Auquier, P., Rufo, M., Tordjman, S., \& Simeoni, M. C. (2013). Quality of life and mental disorders of adolescents living in French residential group homes. Child Welfare Journal, 92(3), 47-71.

Cardoso, C. F., Drummond, A. F., Lages, E., Pretti, H., Ferreira, E. F., \& Abreu, M. H. N. (2011). The dental aesthetic index and dental health component of the index of orthodontic treatment need as tools in epidemiological studies. International Journal of Environmental Research and Public Health, 8(8), 32773286. 10.3390/ijerph9093280

Cioffi, I., Perrotta, S., Ammendola, L., Cimino, R., Vollaro, S., Paduano, S., \& Michelotti, A. (2014). Social impairment of individuals suffering from different types of chronic orofacial pain. Progress in Orthodontics, 15(1), 27. 10.1186/s40510-014-0027-Z

Colussi, P. R. G., Hugo, F. N., Muniz, F. W. M. G., \& Rösing, C. K. (2017). Oral health-relatedquality of life and associated factors in Brazilian adolescents. Brazilian Dental Journal, 28(1), 113-120. 10.1590/0103-6440201701098

Cortes, I., Marcenes, W., \& Sheiham, A. (2002). Impact of traumatic injuries to the permanent teethon the oral health-related quality of life in 12-14-year-old children. Community Dentistry and Oral Epidemiology, 30(3), 193-198. 10.1034/j.1600-0528.2002.300305.x

Costa, R. N., Abreu, M. H. N. G. D., Magalhães, C. S. D., \& Moreira, A. N. (2011) Validity of two occlusal indices for determining orthodontic treatment needs of patients treated in a public university in Belo Horizonte, Minas Gerais State, Brazil. Cadernos de Saúde Pública, 27(3), 581-590. 10.1590/s0102$311 \times 2011000300018$

Crone, E. A., \& Dahl, R.E. (2012). Understanding adolescence as a period of social-affectiveengagement and goal flexibility. Nature Reviews Neuroscience, 13(9), 636-50. 10.1038/nrn3313

Cservenka, A., Stroup, M. L., Etkin, A., \& Nagel, B. J. (2015). The effects of age, sex, and hormones on emotional conflict-related brain response during adolescence. Brain and Cognition, 99(2), 135-150. 10.1016/j.bandc.2015.06.002

Dahl, R. E., \& Gunnar, M. R. (2009). Heightened stress responsiveness and emotional reactivity duringpubertal maturation: implications for psychopathology. Development and Psychopathology, 21(1), 1-6. 10.1017/S0954579409000017

Dantas-Neta, N. B., Moura, L. D. F. A. D., Cruz, P. F., Moura, M. S., Paiva, S. M., \& Martins, C. C. (2016) Impact of Molar-Incisor Hypomineralization on Oral Health-Related Quality of Life in Schoolchildren. Brazilian Oral Research, 30(1), e117. 10.1590/1807-3107BOR-2016.vol30.0117

Dean, H. T. (1934) Classification of mottled enamel diagnosis. The Journal of the American Dental Association, 21(8),1421-1426.

Deli, R., Macrì, L. A., Mannocci, A., \& La Torre, G. (2009). Measuring Quality of Life in TMD: Use of SF-36. Italian Journal of Public Health, 6(2), 156163.

Dunn, K. M., Jordan, K. P., Mancl, L., Drangsholt, M. T., \& Le Resche, L. (2011). Trajectories of Pain in Adolescents: A Prospective Cohort Study. Pain. 152(1), 66-73. 10.1016/j.pain.2010.09.006.

Franco, A. L., Fernandes, G., Goncalves, D. A., Bonafé, F. S., \& Camparis, C. M. (2014). Headacheassociated with temporomandibular disorders among young Brazilian adolescents. The Clinical Journal of Pain, 30(4), 340-345. 10.1097/AJP.0b013e31829ca62f.

Franco-Micheloni, A. L., Fernandes, G., Gonçalves, D. A. D. G., \& Camparis, C. M. (2014). Temporomandibular disorders among Brazilian adolescents: reliability and validity of a screening questionnaire. Journal of Applied Oral Science, 22(4), 314-322. 10.1590/1678-775720130694.

Fillingim, R. B. et al. (2013). Psychological factors associated with development of TMD: the OPPERA prospective cohort study. Journal of Pain, 14(12), T75-T90. 10.1016/j.jpain.2013.06.009.

Gardea, M. A., Gatchel, R. J., \& Mishra, K. D. (2001). Long-Term Efficacy of Biobehavioral Treatment of Temporomandibular Disorders. Journal of Behavioral Medicine, 24(4), 341-359. 10.1023/a:1010682818427. 
Research, Society and Development, v. 10, n. 14, e379101421981, 2021

(CC BY 4.0) | ISSN 2525-3409 | DOI: http://dx.doi.org/10.33448/rsd-v10i14.21981

Glick, M., Williams, D. M., Kleinman, D. V., Vujicic, M., Watt, R. G., \& Weyant, R. J. (2016). Anew definition for oral health developed by the FDI World Dental Federation opens the door to a universaldefinition of oral health. Brazilian Dental Journal, 221(12), 792. 10.1038/sj.bdj.2016.953.

Godoy, F., Rosenblatt, A., \& Godoy-Bezerra, J. (2007). Temporomandibular disorders andassociated factors in Brazilian teenagers: a cross-sectional study. Int Journal of Prosthodontics, 20(6), 599-604.

Hongxing, L., Astrøm, A. N., List, T., Nilsson, I. M., \& Johansson, A. (2016). Prevalence oftemporomandibular disorder pain in Chinese adolescents compared to an age-matched Swedish population. Journal of Oral Rehabilitation, 43(4), 241-248. 10.1111/joor.12366

Jung, M. H. (2016). Quality of life and self-esteem of female orthognathic surgery patients. Journal of Oral and Maxillofacial Surgery, 74(6), 1240-e1. 10.1016/j.joms.2016.01.046

Karibe, H., Shimazu, K., Okamoto, A., Kawakami, T., Kato, Y., \& Warita-Naoi, S. (2015). Prevalence and association of self-reported anxiety, pain, and oral parafunctional habits with temporomandibular disorders in Japanese children and adolescents: a cross-sectional survey. BMC Oral Health, 15(1), 8. $10.1186 / 1472-6831-15-8$

Keles, S., Abacigil, F., \& Adana, F. (2018). Oral health status and oral health related quality of lifein adolescent workers. Clujul Medical Journal, 91(4), 462. $10.15386 /$ cjmed-1027

La Torre, G. C., Câmara-Souza, M. B., Lora, V. R. M. M., Guarda-Nardini, L., Conti, P. C. R., Garcia, R. M. R., Cury, A. A. D. B., \& Manfredini, D. (2018). Prevalence of psychosocial impairment in temporomandibular disorder patients: A systematic review. Journal of Oral Rehabilitation, 45(11), 881-889. 10.1111/joor. 12685

Lemos, G. A., Paulino, M. R., Forte, F. D. S., Beltrão, R. T. S., \& Batista, A. U. D. (2015). Influence of temporomandibular disorder presence and severity on oral health-related quality of life. RevistaDor, 16(1), 10-14.

Li, M. H., \& Bernabé, E. (2016). Tooth wear and quality of life among adults in the United Kngdom. Journal of Dentistry, 55, 48-53. 10.1016/j.jdent.2016.09.013

Lobbezoo, F., Ahlberg, J., Raphael, K.G., Wetselaar, P., Glaros, A. G., Kato, T., \& Koyano, K. (2018). International consensus on the assessment of bruxism: Report of a work in progress. Journal of Oral Rehabilitation, 45(11), 837-844. 10.1111/joor.12663

Locker, D. (2001). Does dental care improve the oral health of older adults? Community Dental Health Journal, 18(1), 7-15.

Lopez, D., Waidyatillake, N., Zaror, C., \& Mariño, R. (2019). Impact of Uncomplicated Traumatic Dental Injuries on The Quality of Life of Children and Adolescents: A Systematic Review and Meta-Analysis. BMCOral Health, 19(1), 224. 10.1186/s12903-019-0916-0

Mangold, A. R., Torgerson, R. R., \& Rogers, I. R. S. (2016). Diseases of the tongue. Clinics in Dermatology, 34(4), 458-469. 10.1016/j.clindermatol.2016.02.018

Medeiros, E. D., do Nascimento, A. M., Mariano, T. E., Sales, H. F. S., \& de Medeiros, P. C. B. (2014).Escala de Felicidade de Lima: Validade Fatorial e Consistência Interna. Revista Psicologia em Pesquisa, 8(2),150-158.

Melis, M., \& Di Giosia, M. (2016). The role of genetic factors in the etiology of temporomandibulardisorders: a review. The Journal of Craniomandibular \& Sleep Practice, 34(1), 43-51. 10.1179/2151090314Y.0000000027

Michel-Crosato, E., Biazevic, M. G. H., \& Crosato, E. (2005). Relationship between dental fluorosis and quality of life: a population based study. Brazilian Oral Research, 19(2), 150-155. 10.1590/s1806-83242005000200014

Miettinen, O., Lahti, S., \& Sipilä, K. (2012). Psychosocial aspects of temporomandibular disordersand oral health-related quality-of-life. Acta Odontolologica Scandinavica, 70(4), 331-336. 10.3109/00016357.2011.654241

Moreno, B. G. D., Maluf, S. A., Marques, A. P., \& Crivello-Junior, O. (2009). Clinical and quality-of-life assessment among women with temporomandibular disorder. Brazilian Journal of Physical Therapy, 13(3), 210-214.

Oliveira, B. H., \& Nadanovsky, P. (2005). Psychometric properties of the Brazilian version of theOral Health Impact Profile-short form. Community Dentistry and Oral Epidemiology, 33(4), 307-314. 10.1111/j.1600-0528.2005.00225.x

Natu, V. P., Yap, A. U. J., Su, M. H., Irfan Ali, N. M., \& Ansari, A. (2018). Temporomandibular Disorder Symptoms and Their Association With Quality of Life, Emotional States and Sleep Quality in South-EastAsian Youths. Journal of Oral Rehabilitation, 45(10), 756-763. 10.1111/joor.12692

Oliveira, C. M., \& Sheiham, A. (2004). Orthodontic treatment and its impact on oral health-related quality of life in Brazilian adolescents. Journal of Orthodontics, 31(1), 20-27. 10.1179/146531204225011364

Oliveira, D. C., Ferreira, F. M., Morosini, I. D. A., Torres-Pereira, C. C., Martins Paiva, S., \& Fraiz, F. C. (2015). Impact of oral health status on the oral health-related quality of life of Brazilian maleincarcerated adolescents. Oral Health and Preventive Dentistry, 13(5), 417-25. 10.3290/j.ohpd.a33922

Ortiz, F. R., Paiva, S. M., Pordeus, I. A., \& Ardenghi, T. M. (2021). Psychometric properties and longitudinal measurement invariance of the Brazilian version of the subjective happiness scale in adolescents. Journal of Clinical and Translational Research, 7(2), 234-240.

Pais-Ribeiro, J. L. (2012). Validação transcultural da escala de felicidade subjectiva de Lyubomirskye Lepper. Psicologia, Saúde \& Doenças, $13(2)$, 157-168. 
Research, Society and Development, v. 10, n. 14, e379101421981, 2021

(CC BY 4.0) | ISSN 2525-3409 | DOI: http://dx.doi.org/10.33448/rsd-v10i14.21981

Paiva Bertoli, F. M., Bruzamolin, C. D., Pizzatto, E., Losso, E. M., Brancher, J. A., \& de Souza, J. F. (2018). Prevalence of diagnosed temporomandibular disorders: A cross-sectional study in Brazilianadolescents. Plos One, 13(2), 1-11. 10.1371/journal.pone.0192254

Paula, J. S., Leite, I. C., Almeida, A. B., Ambrosano, G. M., Pereira, A. C., \& Mialhe, F. (2012). The influence of oral health conditions, socioeconomic status and home environment factors on schoolchildren's self-perception of quality of life. Health and Quality of Life Outcomes, 10(1), 6. 10.1186/1477-7525-10-6

Paulino, M. R., Moreira, V. G., Lemos, G. A., Silva, P. L. P. D., Bonan, P. R. F., \& Batista, A. U. D. (2018). Prevalence of signs and symptoms of temporomandibular disorders in college preparatory students: associations with emotional factors, parafunctional habits, and impact on quality of life. Ciência \& Saúde Coletiva, 23(1), 173-186. 10.1590/1413-81232018231.18952015

Peres, K. G., Peres, M. A., Araujo, C. L., Menezes, A. M., \& Hallal, P. C. (2009). Social and dental status along the life course and oral health impacts in adolescents: a population-based birth cohort. Health and Quality of Life Outcomes, 7(1), 95. 10.1186/1477-7525-7-95

Ravens-Sieberer, U., Erhart, M., Gosch, A., Wille, N., \& European KIDSCREEN Group. (2008) Mental health of children and adolescents in 12 European countries-results from the European KIDSCREEN study. Clin Psychol Psychother, 15(3):154-63. 10.1002/cpp.574

Reamy, B. V., Derby, R., \& Bunt, C. W. (2010). Common tongue conditions in primarycare. American Academy of Family Physicians, 81(5), $627-634$.

Resende, C. M. B. M. D., Alves, A. C. D. M., Coelho, L. T., Alchieri, J. C., Roncalli, Â. G., \& Barbosa, G. A. S. (2013). Quality of life and general health in patients with temporomandibular disorders. Brazilian Oral Research, 27(2), 116-121. Quality of life and general health in patients with temporomandibular disorders. Brazilian Oral Research, 27(2), 116-121.

Resende, C. M. B. M., Rocha, L. G. D. S., Paiva, R. P., Cavalcanti, C. S., Almeida, E. O., Roncalli, A. G., \& Barbosa, G. A. S. (2020). Relationship between anxiety, quality of life, and sociodemographic characteristics and temporomandibular disorder. Oral Surgery, Oral Medicine, Oral Pathology, Oral Radiology and Endodontics, 129(2): 125-132. 10.1016/j.oooo.2019.10.007

Rosa, G. N., Del Fabro, J. P., Tomazoni, F., Tuchtenhagen, S., Alves, L. S., \& Ardenghi,, T. M. (2016). Association of Malocclusion, Happiness, and Oral Health-Related Quality of Life (OHRQoL) in Schoolchildren. Journal of Public Health Dentistry, 76(2), 85-90. 10.1111/jphd.12111

Sawyer, M. G., Whaites, L., Rey, J. M., Hazell, P. L., Graetz, B. W., \& Baghurst, P. (2002). Health-related quality of life of children and adolescents with mental disorders. Journal of the American Academy of Child \& Adolescents Psychiatry, 41(5), 530-7. 10.1097/00004583-200205000-00010

Sena, M. F. D., Mesquita, K. S. F. D., Santos, F. R. R., Silva, F. W. G., \& Serrano, K. V. D. (2013). Prevalence of temporomandibular dysfunction in children and adolescents. Revista Paulista de Pediatris, 31(4), 538-545. 10.1590/S0103-05822013000400018

Silva, M. D. F., Vedovello, S. A., Vedovello Filho, M., Venezian, G. C., Valdrighi,, H. C.,\&Degan, V. V. (2017). Temporomandibular Disorders and Quality of Life Among 12-year-old Schoolchildren. The Journal of Craniomandibular \& Sleep Practice, 35(6), 392-396. 10.1080/08869634.2016.1248590

Simoen, L., Van den Berghe, L., Jacquet, W., \& Marks, L. (2020). Depression and anxiety levels inpatients with temporomandibular disorders: comparison with the general population. Clinical Oral Investigations, (11),1-7. 10.1007/s00784-020-03260-1

Slade, G. D. (1997). Derivation and validation of a short-form oral health impact profile. Community Dentistry and Oral Epidemiology, 25(4), 284-290. 10.1111/j.1600-0528.1997.tb00941.x

Soe, K. K., Gelbier, S., \& Robinson, P. G. (2004). Reliability and validity of two oral health related quality of life measures in Myanmar adolescents. Community Dental Health Journal, 21(4), 306-311.

Sönmez, H., Sari, S., Oray, G. O., \& Camdeviren, H. (2001). Prevalence of temporomandibular dysfunction in Turkish children with mixed and permanent dentition. Journal of Oral Rehabilitation, 28(3), 280-285.

Sun, L., Wong, H. M., McGrath, C. P., Sun, L., \&Wong, H. M. (2017). Relationship between the severity of malocclusion and oral health related quality of life: a systematic review and meta-analysis. Oral Health and Preventive Dentistry, 15(6), 503-17. 10.3290/j.ohpd.a38994

Thomson, W. M., \& Broder, H. L. (2018). Oral-Health-Related Quality of Life in Children and Adolescents. Pediatric Clinics of North America, 65(5), 107384. 10.1016/j.pcl.2018.05.015

Tuchtenhagen, S., Bresolin, C. R., Tomazoni, F., da Rosa, G. N., Del Fabro, J. P., Mendes, F. M., Antunes, J. L. F., \& Ardenghi, T. M. (2015). The Influence of Normative and Subjective Oral Health Status on Schoolchildren's Happiness. BMC Oral Health, 15(1), 15. 10.1186/1472-6831-15-15

Turner, J. A., Mancl, L., \& Aaron, L. A. (2006). Short- and Long-Term Efficacy of Brief Cognitive-Behavioral Therapy for Patients With Chronic Temporomandibular Disorder Pain: A Randomized, Controlled Trial. Pain, 121(3), 181-194. 10.1016/j.pain.2005.11.017

Vargas-Ferreira, F., Praetzel, J. R., \& Ardenghi, T. M. (2011). Prevalence of tooth erosion and associated factors in 11-14-year-old Brazilian schoolchildren. Journal of Public Health Dentistry, 71(1), 6-12. 10.1111/j.1752-7325.2010.00194.x

Velly, A. M., Look, J. O., Carlson, C., Lenton, P. A., Kang, W., Holcroft, C. A., \& Fricton, J. R. (2011). The effect of catastrophizing and depression on chronic pain-a prospective cohort study of temporomandibular muscle andjoint pain disorders. Pain, 152(10), 2377-2383 10.1016/j.pain.2011.07.004

Weerheijm, K. L., Duggal, M., Mejàre, I., Papagiannoulis, L., Koch, G., Martens, L. C., \& Hallonsten, A. L. (2003). Judgement criteria for Molar Incisor Hypomincralisation (MIH) in epidemiologicstudies: a summary of the European meeting on MIH held in Athens. European Journal of Paediatric Dentistry, 4(3), 110-114.

Whoqol Group. (1995). The World Health Organization quality of life assessment (WHOQOL):position paper from the World Health Organization. Social Science \& Medicine, 41(10), 1403-1409. 10.1016/0277-9536(95)00112-k 
Research, Society and Development, v. 10, n. 14, e379101421981, 2021

(CC BY 4.0) | ISSN 2525-3409 | DOI: http://dx.doi.org/10.33448/rsd-v10i14.21981

Yap, A. U., Qiu, L. Y., Natu, V. P., \& Wong, M. C. M. (2020). Functional, physical and psychosocial impact of Temporomandibular Disorders in adolescents and young adults. Medicina Oral, Patologia Oral, Cirurgia Bucal, 25(2), e188-94. 10.4317/medoral.23298

Zucoloto, M. L., Maroco, J., \& Campos, J. A. D. B. (2016). Impact of oral health on health-relatedquality of life: a cross-sectional study. BMC Oral Health, 16(1), 55. 10.1186/s12903-016-0211-2 